\title{
Mucopolysaccharidosis type I: identification of novel mutations that cause Hurler/Scheie syndrome in Chinese families
}

\author{
Guey-Jen Lee-Chen, Tso-Ren Wang
}

\begin{abstract}
The complementary and genomic DNA segments of the $\alpha$-L-iduronidase gene from two Chinese mucopolysaccharidosis type I Hurler/Scheie (MPS IH/S) patients were amplified by polymerase chain reaction (PCR) and DNA sequencing was done to study their molecular lesions. Patient W3 has heterozygous mutations; the maternal allele has M1I (G to $A$ transition in the initiation codon ATG) and the paternal allele has Y343X (C to $G$ transversion in exon 8 leading to in frame deletion of codons 325-343 from the mRNA owing to false splicing). Patient W2 is homozygous for mutation T364M (C to $T$ transition in codon 364). The mutation was paternally inherited. A de novo deletion or gene conversion event may have resulted in apparent homozygosity for T364M. Expression of Y343X and T364M showed trace amounts of $\alpha$-L-iduronidase activity compared to that of normal cDNA upon transfection into COS-7 cells.

(F Med Genet 1997;34:939-941)
\end{abstract}

Keywords: mucopolysaccharidosis type I; $\alpha$-Liduronidase; novel mutations

$\alpha$-L-iduronidase (IDUA, $\alpha$-L-iduronide iduronohydrolase, EC 3.2.1.76) is one of the enzymes involved in degradation of the glycosaminoglycans heparan sulphate and dermatan sulphate. Loss or marked reduction of IDUA activity results in the autosomal recessive disease mucopolysaccharidosis type I (MPS I). MPS I involves a broad spectrum of clinical symptoms and can be divided into three clinical subtypes: Hurler, Hurler/Scheie, Revised version accepted for publication 9 April 1997

Table 1 Specific PCR conditions

\begin{tabular}{|c|c|c|c|c|}
\hline $\begin{array}{l}\text { Amplified } \\
\text { fragment }\end{array}$ & $\begin{array}{l}\text { Primer pairs and } \\
\text { postition }\end{array}$ & $\begin{array}{l}\text { Annealing } \\
\text { temperature } \\
\left({ }^{\circ} \mathrm{C}\right)\end{array}$ & Conditions & $\begin{array}{l}\text { Product size } \\
\text { (bp) }\end{array}$ \\
\hline $5^{\prime} \mathrm{cDNA}$ & $\begin{array}{l}\text { ID60 (76-99) } \\
\text { ID61 (906-883) }\end{array}$ & 58 & $\begin{array}{l}1.5 \mathrm{mmol} / 1 \mathrm{MgCl}_{2} \\
10 \% \mathrm{DMSO}\end{array}$ & 841 \\
\hline $3^{\prime} \mathrm{cDNA}$ & $\begin{array}{l}\text { ID69 }(857-880) \\
\text { ID63 }(2149-2126)\end{array}$ & 57 & $\begin{array}{l}1.5 \mathrm{mmol} / 1 \mathrm{MgCl}_{2} \\
10 \% \mathrm{DMSO}\end{array}$ & 1293 \\
\hline Exon 1 & $\begin{array}{l}\text { ID58 (496-519) } \\
\text { ID65 }(740-717)\end{array}$ & 66 & $\begin{array}{l}2.5 \mathrm{mmol} / \mathrm{l} \mathrm{MgCl}_{2} \\
10 \% \mathrm{DMSO}\end{array}$ & 245 \\
\hline Intron 2 & $\begin{array}{l}\text { ID53 }(1061-1080) \\
\text { ID54 }(1853-1834)\end{array}$ & 65 & $2.5 \mathrm{mmol} / 1 \mathrm{MgCl}_{2}$ & $630,715,800$ \\
\hline Exon 3 & $\begin{array}{l}\text { ID49 }(97-116) \\
\text { ID36 }(540-519)\end{array}$ & 66 & $1.5 \mathrm{mmol} / 1 \mathrm{MgCl}_{2}$ & 444 \\
\hline Exon 8 & $\begin{array}{l}\text { ID106 (1760-1783) } \\
\text { ID89 (2457-2434) }\end{array}$ & 65 & $1.0 \mathrm{mmol} / 1 \mathrm{MgCl}_{2}$ & 699 \\
\hline Exon 9 & $\begin{array}{l}\text { ID90 (2434-2457) } \\
\text { ID109 }(2804-2781)\end{array}$ & 61 & $1.0 \mathrm{mmol} / 1 \mathrm{MgCl}_{2}$ & 370 \\
\hline
\end{tabular}

*The nucleotide positions for PCR were from reference 2 for 5' and 3' CDNA amplification, reference 3 for exons $1,2,3,8$, and 9 amplification, and reference 11 for intron 2 amplification. and Scheie syndromes. ${ }^{1}$ Recently the IDUA gene was cloned and the cDNA sequence determined. ${ }^{2}{ }^{3}$ The $2.1 \mathrm{~kb}$ cDNA contains 14 exons spanning approximately $19 \mathrm{~kb}$ on chromosome 4pl6.3. ${ }^{4}$ Mutation screening in patients with MPS I identified a number of mutations underlying the disorder. The reported heterogeneity of MPS I includes common mutations, W402X and Q70X, and other rare mutations, such as single base substitutions, deletions, insertions, and splicing site mutations. ${ }^{5}$ Characterisation of gene mutations is an important prerequisite to analysing genotype/phenotype correlation and patient selection for therapy such as bone marrow transplantation. ${ }^{6}$

In this study, the molecular lesions of two 10 year old Chinese MPS IH/S patients with short stature, coarse face, and severe skeletal deformities were investigated. Both patients showed normal intelligence based on their good performance in school. Poly(A) ${ }^{+}$RNA from the patients and a normal subject's skin fibroblast cells was prepared. Two pairs of primers that encompass IDUA cDNA sequences 76-906 and 857-2149 (table 1), respectively, were used for PCR amplification on reverse transcribed cDNA. The amplified cDNA fragments were subcloned and sequenced by automated online DNA Sequencer. The results are summarised in table 2. In patient W3, one IDUA allele has MII (a G to A transition in initiation codon) and an in frame deletion of the whole of exon 2, whereas the other allele has Y343X (an in frame deletion of nt 1061-1117 in exon 8). Patient W3 is heterozygous for M1I (fig 1, lane 2). The mutation M1I also appeared in the patient's mother (fig 1, lane 3). The deleted exon 2 in M1I was the result of alternative splicing since MII appeared in the PCR amplified product containing exons 1-2 (data not shown). With M1I and deleted exon 2, the expressed IDUA protein has a deletion of N-terminal 132 residues that constitutes signal peptide. It is possible that this alteration prevents correct cotranslational transport of the protein into the endoplasmic reticulum and its further processing and transport to the lysosome. The recurrent Y343X was the result of a C to $G$ transversion at nt 1117 leading to an in frame deletion of 19 residues in exon $8 .^{7}$ Patient W3 is heterozygous for Y343X (fig 1, lane 5). The mutation Y343X has been inherited from patient W3's father (fig l, lane 4). Expression of Y343X in COS-7 cells showed retention of a very low level of IDUA activity (table 3 ). 
Table 2 Summary of the mutations and predicted protein alterations in the MPS IH/S patients

\begin{tabular}{|c|c|c|c|c|c|}
\hline Mutation & Nucleotide alteration & Protein alteration (residue No) & Patient & Allele & Comments \\
\hline M1I & ATG $\rightarrow$ ATA (exon 1) & $\begin{array}{l}\text { No initition at codon } 1 \\
\text { Deletion of } 47 \text { aa }(54-100)\end{array}$ & W3 & 1 & Alternative spicing of exon 2 \\
\hline $\begin{array}{l}\text { Y343X } \\
\text { T364M }\end{array}$ & $\begin{array}{l}\text { TAC } \rightarrow \text { TAG (exon 8) } \\
\text { ACG } \rightarrow \text { ATG (exon 8) }\end{array}$ & $\begin{array}{l}\text { Deletion of } 19 \text { aa }(325-343) \\
\text { Thr } \rightarrow \text { Met at codon } 364\end{array}$ & $\begin{array}{l}\text { W3 } \\
\text { W2 }\end{array}$ & $\begin{array}{l}2 \\
\text { Homozygous }\end{array}$ & $\begin{array}{l}\text { False splicing } \\
\text { In addition to } \\
\text { R105Q (CGG } \rightarrow \text { CAG) } \\
\text { A361T (GCG } \rightarrow \text { ACG) } \\
\text { V454I (GTC } \rightarrow \text { ATC) }\end{array}$ \\
\hline
\end{tabular}
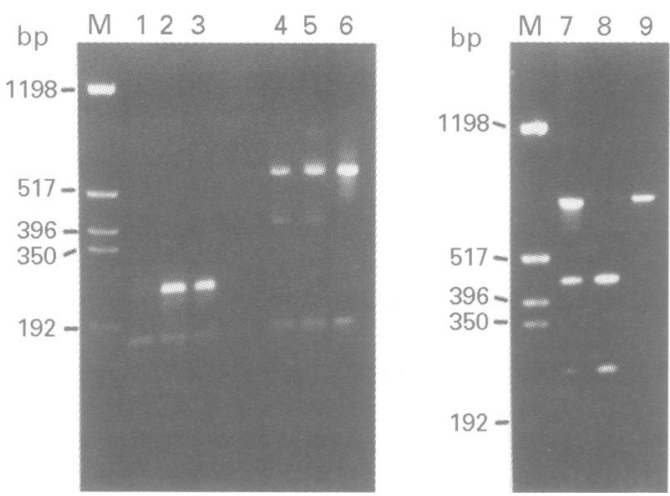

Figure 1 DNA PCR and restriction analysis of mutations in the MPS IH/S patients. The amplified 245 bp DNA fragments containing exon 1 (lanes 1-3) or 699 bp DNA fragments containing exon 8 (lanes 4-6) from patient W3's father (lanes 1 and 4), W3 (lanes 2 and 5), and mother (lanes 3 and 6) were digested with NlaIII (lanes 1-3) or HaeII (lanes 4-6) and fractionated on a $1.8 \%$ agarose gel. Mutation M1I eliminates a NlaIII restriction site on the $P C R$ product so that, on digestion, 237 and $8 \mathrm{bp}$ fragments appeared instead of wild type 154, 83, and 8 bp fragments. Mutation Y343X creates a new Haell restriction site on the PCR product so that, on digestion, 381,168 , and 150 bp fragments appeared instead of wild type 531 and $168 \mathrm{bp}$ fragments. The amplified $699 \mathrm{bp} D N A$ fragments from patient W2's father (lane 7), W2 (lane 8), and mother (lane 9) were digested with SphI and fractionated on a $1.4 \%$ agarose gel. The mutation T364M creates a new SphI restriction site on the PCR product so that, on digestion, 444 and $255 \mathrm{bp}$ fragments appeared instead of wild type 699 bp fragment. Lane $M$ (HinfI digest of pGEM4 DNA) is used as a size marker.

In patient W2, only $\mathrm{T} 364 \mathrm{M}$ (a C to $\mathrm{T}$ transition at nt 1179 in codon 364) was detected. Patient W2 is homozygous for T364M (fig 1, lane 8), a non-conserved amino acid substitution at position 364 of the IDUA protein. Threonine at 364 is reportedly conserved across species in the human, ${ }^{2}$ canine, ${ }^{8}$ and murine ${ }^{9}$ IDUA genes. Expression of T364M showed retention of $1.3 \%$ IDUA activity (table 3). The mutation T364M was detected in the patient's father (fig 1, lane 7), whereas the mother has no T364M (fig 1, lane 9). The

Table 3 Expression of a-L-iduronidase activity in transfected COS-7 cells

\begin{tabular}{lcc}
\hline Transfection vector & $\begin{array}{l}a-L \text {-iduronidase activity } \\
\text { (nmol/h/mg protein) }\end{array}$ & $\begin{array}{l}\text { Total } \\
\text { (\% of normal) }\end{array}$ \\
\hline pcDNA3 & 80.9 & 0.0 \\
pcDNA3-IDUA & 445.8 & 100.0 \\
pcDNA3-IDUA/Y343X & 84.8 & 1.1 \\
pcDNA3-IDUA/T364M & 85.6 & 1.3 \\
\hline
\end{tabular}

A wild type IDUA cDNA was subcloned into pcDNA3 (Invitrogen Corporation) to give pcDNA3-IDUA. The pcDNA3-IDUA/Y343X was derived from pcDNA3-IDUA by replacing a EarI-BstEII fragment (nt 944-1453) with a fragment excised from the $3^{\prime}$ cDNA clone of patient W3. The pcDNA3-IDUA/T364M was derived from pcDNA3-IDUA by replacing a AlwNI-FspI fragment (nt 1076-1233) with a fragment excised from the $3^{\prime}$ cDNA clone of patient W2. COS-7 cells were transfected with plasmid DNA by lipofection procedure ${ }^{15}$ Cultures of transfected cells were collected, and extracts prepared and assayed for IDUA activity. ${ }^{16}$ The activity of endogenous $\alpha$-L-iduronidase in COS-7 cells was subtracted before the percentage of normal was calculated. Efficiency of transfection was similar in all dishes by 3' IDUA cDNA PCR amplification of transfected genomic DNA (data not shown).
A

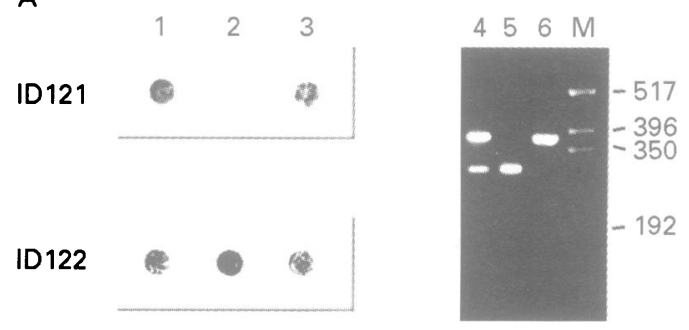

B

1

\begin{tabular}{lrr|r} 
& & & \\
Q33H & 11 & & \\
VNTR & 13 & & \\
R1050 & 12 & & 32 \\
A361T & 12 & & 12 \\
T364M & $*$ & & 12 \\
V454l & 12 & & 11 \\
& & 11 & \\
& & 32 & \\
& & 22 & \\
& & 22 & \\
& & & \\
& & 22 &
\end{tabular}

Figure 2 (A) Allele specific oligonucleotide (ASO) hybridisation of $A 631 T$ polymorphism and restriction analysis of $V 454 I$ polymorphism. The A361T was detected by ASO ID122. The duplicate membranes containing amplified 699 bp DNA fragments from patient W2's father (lane 1), W2 (lane 2), and mother (lane 3) were hybridised with DIG-ddUTP labelled ID121 (upper panel) or 122 (lower panel). The V454I creates a new SfaNI restriction site. The amplified $370 \mathrm{bp} D N A$ fragments containing exon 9 from patient W2's father (lane 4), W2 (lane 5), and mother (lane 6) were digested with SfaNI and fractionated on a $1.8 \%$ agarose gel. Lane $M$ (HinfI digest of pGEM4 DNA) is used as size marker. (B)

Pedigree and haplotype analysis of W2's family. Haplotypes for polymorphic markers $O 33 H, V N T R, R 105 O, A 361 T$, and V454I are shown under each person. The Q33H was detected by Nsp (7524)I restriction on PCR amplified DNA using primers ID58 and 65. The VNTR was examined by $1.2 \%$ agarose gel electrophoresis of $P C R$ amplified DNA using primers ID53 and 54. The R105Q was detected by AlwNI restriction on PCR amplified DNA using primers ID49 and 36. For Q33H, R105Q, A361T, and V454I, numbers 1 and 2 represent alleles without (1) or with (2) polymorphic change. For VNTR, numbers 1-3 represent alleles with 800,715 , and $630 \mathrm{bp} P C R$ amplified product. Haplotypes cosegregating with the disease phenotype are indicated by bold numbers.

genotypes at five polymorphic sites $\mathrm{Q} 33 \mathrm{H},{ }^{10}$ VNTR, ${ }^{11} \mathrm{R} 105 \mathrm{Q},{ }^{2} \mathrm{~A} 361 \mathrm{~T},{ }^{12}$ and $\mathrm{V} 454 \mathrm{I}^{13}$ in the IDUA gene in patient W2's family were determined (fig $2 \mathrm{~A}$ ) and used to generate their haplotypes. The paternal allele $1,3,2,2,2$ cosegregated with the mutation T364M (fig 2B). When the maternal allele from the patient was compared with the alleles of the mother, a discrepancy in V454I was found (fig 2A, lanes 5 and 6). The patient was homozygous for polymorphisms A314, T388, T410, and R489 (data not shown) in addition to A361T and V454I. The homozygosity for polymorphisms in exons 8-10 and the discrepancy in T364M 
and V454I between the patient and the mother suggest the possibility of hemizygosity of this region of the IDUA gene in the patient. Alternatively, a double stranded break $^{14}$ gene conversion event might have resulted in homozygosity for T364M.

In conclusion, we have identified novel mutations in the IDUA gene in two Chinese MPS IH/S patients. The new missense mutations expand the heterogeneous spectrum of MPS I. Further characterisation of mutant alleles will provide a useful tool for diagnosis, counselling, and assessment of experimental protocols for MPS I syndrome.

We thank Y C Cherng, C K Wang, and K R Day for their excellent technical assistance and Drs B C Chung, K Fang, and W L Hwu for their helpful discussion and comment. This work was supported by grants NSC83-0211-B-003-001 and NSC84231 1-B-003-002 from the National Science Council, Executive Yuan, Republic of China

1 Neufeld EF, Muenzer J. The mucopolysaccharidoses. In: Scriver CR, Beaudet AL, Sly WS, Valle D, eds. The metabolic basis of inherited diseases. 6th ed. New York: McGraw-Hill, 1989:1565-87.

2 Scott HS, Anson DS, Orsborn AM, et al. Human $\alpha$-L-iduronidase $\mathrm{cDNA}$ isolation and expression. Proc Natl Acad Sci USA 1991;88:9695-9.

3 Scott HS, Guo XH, Hopwood JJ, Morris CP. Structure and sequence of the human $\alpha$-L-iduronidase gene. Genomics 1992;13:1311-13.

4 Scott HS, Ashton LJ, Eyre HJ, et al. Chromosomal localization of the human $\alpha-\mathrm{L}$-iduronidase gene (IDUA) to tion of the human $\alpha$-L-iduronidase $g$ -

5 Scott HS, Bunge S, Gal A, Clarke IA, Morris CP, Hopwood JJ. Molecular genetics of mucopolysaccharidosis type I:
. diagnostic, clinical, and biological implications. Hum Mutat 1995;6:288-302

6 Hopwood JJ, Vellodi A, Scott HS, et al. Long-term clinical progress in bone marrow transplanted mucopolysaccharidosis type I patients with a defined genotype. 7 Inherit dosis type I patients with a

7 Tieu PT, Menon K, Neufeld EF. A mutant stop codon (TAG) in the IDUA gene is used as an acceptor splice site in a patient with Hurler syndrome (MPS IH). Hum Mutat 1994;2:333-6.

8 Stoltzfus LJ, Sosa-Pineda B, Moskowitz SM, et al. Cloning and characterization of cDNA encoding canine $\alpha$-Liduronidase. 7 Biol Chem 1992;267:6570-5.

9 Clarke LA, Nasir J, Zhang H, et al. Murine $\alpha$-L-iduronidase: cDNA isolation and expression. Genomics 1994;24:311-16.

10 Scott HS, Litjens T, Hopwood JJ, Morris CP. PCR detection of two RFLPs in exon I of the $\alpha$-L-iduronidase (IDUA) gene. Hum Genet 1992;90:327.

11 Scott HS, Nelson PV, MacDonald ME, Gusella JF, Hopwood JJ, Morris CP. An 86-bp VNTR within IDUA is the basis of the D4S111 polymorphic locus. Genomics 1992;14:1118-20.

12 Scott HS, Nelson PV, Litjens T, Hopwood JJ, Morris CP. Multiple polymorphisms within the $\alpha$-L-iduronidase gene (IDUA): implications for a role in modification of MPS-I disease phenotype. Hum Mol Genet 1993;2:1471-3.

13 Bunge S, Kleijer WJ, Steglich C, et al. Mucopolysaccharidosis type I: identification of 8 novel mutations and determination of the frequency of the two common a-L iduronidase mutations (W402X and Q70X) among European patients. Hum Mol Genet 1994;3:861-6.

14 Szostak JW, Orr-Weaver TL, Rothstein RJ. The doublestrand-break repair model for recombination. Cell 1983;33: 25-35.

15 Hawley-Nelson P. Ciccarone V, Gebeyehu G, Jessee J, Felgner PL. LipofectAMINE reagent: a new, higher efficiency polycationic transfection reagent. Focus 1993;15: 73-9.

16 Hopwood JJ, Muller V, Smithson A, Baggett N. A fluorometric assay using 4-methylumbelliferyl $\alpha$-Liduronide for the estimation of $\alpha$-L-iduronidase activity and the detection of Hurler and Scheie syndromes. Clin Chim Acta 1979;92:257-65. 